\title{
Miejsca węzlowe w systemie zieleni, jako zagadnienie integracji przestrzeni miejskiej
}

\author{
Kinga Zinowiec-Cieplik \\ Katedra Projektowania Architektoniczno-Urbanistycznego, \\ Wydział Architektury Politechniki Warszawskiej, e-mail: ckinga@wp.pl
}

Streszczenie: System zieleni miejskiej, znacząca część krajobrazu zurbanizowanego, rozumiany jako System Przyrodniczy Miasta (SPM) oznaczający zgodnie z definicją ,obszary o specyficznych cechach, zidentyfikowanych $i$ wyznaczonych z zastosowaniem zasad ekologii i ekologii krajobrazu, których głównym zadaniem jest regulowanie funkcjonowania środowiska przyrodniczego w mieście” (Szulczewska B., Kaliszuk E. 2005 [1]) przybiera pierwszoplanową rolę w kontekście budowania zrównoważonego i trwałego miejskiego środowiska życia. Podobnie jak w ogólnie przyjętej teorii kompozycji urbanistycznej (Lynch. K. 1960 [5], Wejchert K. 1974 [9]) strukturę SPM krystalizują elementy węzłowe istotne, w tym ujęciu, ze względu na „znaczenie klimatyczne, hydrologiczne i/lub biologiczne” (Szulczewska B., Kaliszuk E.2005 [1]). Rozpatrując zagadnienia kompozycji miasta i jego krajobrazu jako skomplikowanego systemu wielu warstw: m.in. komunikacji, zabudowy, infrastruktury i zieleni trzeba podkreślić znaczącą rolę ich przenikania, która dopełnia istotę funkcjonowania bardzo dynamicznego i zmiennego organizmu. Zmiany w jednej z warstw powodują zakłócenia w pozostałych. Dlatego ważne stają się relacje wiążące poszczególne warstwy, a ich nagromadzenie i dynamika będą decydowały czy powstanie ostatecznie miejsce węzłowe. Struktura zieleni jest zbyt delikatna względem brutalności układów komunikacyjnych i nierzadko zabudowy. A jednak, w świetle współczesnych potrzeb budowania zdrowego, przyjaznego środowiska życia oraz kreatywnego otwartego na zmiany podejścia projektowego (Prominski M.2005 [26]), w systemie przyrodniczym tkwi integracyjny potencjał przestrzeni miejskiej.

Słowa kluczowe: miejsca węzłowe, system przyrodniczy miasta, integracja przestrzeni miejskiej.

\section{Wprowadzenie}

System zieleni miejskiej, znacząca część krajobrazu zurbanizowanego, rozumiany jako System Przyrodniczy Miasta (SPM) oznaczający zgodnie z definicją ,, obszary o specyficznych cechach, zidentyfikowanych $i$ wyznaczonych z zastosowaniem zasad ekologii i ekologii krajobrazu, których głównym zadaniem jest regulowanie funkcjonowania środowiska przyrodniczego w mieście" (Szulczewska B., Kaliszuk E., 2005 [1]) przybiera pierwszoplanową rolę w kontekście budowania zrównoważonego i trwałego miejskiego środowiska życia.

Większość badaczy SPM bada system pod kątem nauk przyrodniczych - co jest jasne i czytelne z punktu widzenia ich zainteresowania (Szulczewska B., Kaliszuk E. 2005 [1], Szumacher I. 2005. [2], Wysocki Cz. 2008 [3], Sikorski P. 2013 [4]). Z perspektywy funkcjonowania miasta jako całości istotne staje się rozpoznanie zazębiania się, przenikania i współdziałania - różnorodnych systemów tak jak w żyjącym organizmie. 
W reakcji na powojenny modernizm blokowisk, od lat 60-tych XX w. nastąpiła zmiana w postrzeganiu miasta oraz jego elementów składowych. Poszukiwano, nowego podejścia kompozycyjnego. Kevin Lynch opublikował, klasyczny „Obraz miasta” (1960 [5]). W parę lat później ukazało się pierwsze wydanie „A City is Not a Tree” (1965 [6]), Christopher’a Aleksandr'a, w którym zaprezentował nowe spojrzenie sieciowe na miasto, które określił jako półkratę (w polskim tłumaczeniu półsieć - semilattice 2013 [6]).

a)

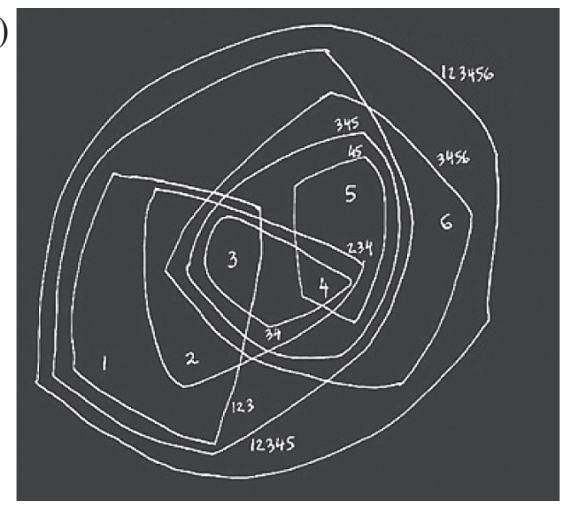

b)

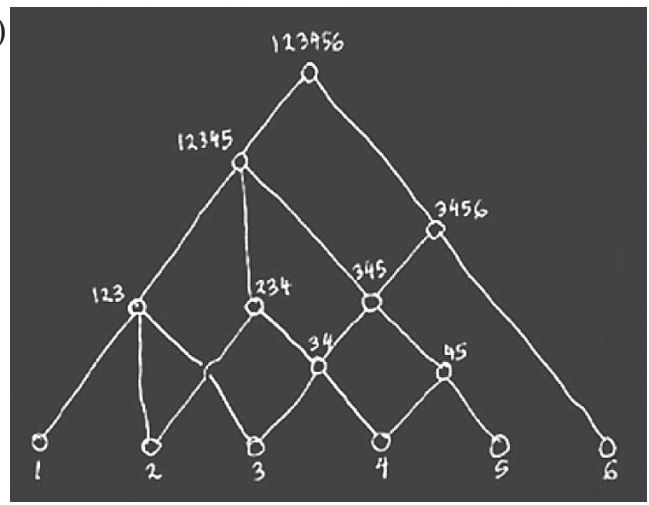

Rys. 1. Diagram A - struktura półkraty/półsieci - nakładanie funkcji; Diagram B - struktura półkraty/ półsieci - współzależność funkcji; rys. Salingaros N. w: Alexander Ch.1965 [6] (źródło:https:// www.rudi.net/books/200)

Wyniki żmudnych badań zespołu Christophera Aleksandra zaowocowały w dwanaście lat później wydaniem „Języka wzorców” (1977 [7]). Analogicznym przesłaniem, z wieloma odniesieniami do K. Lyncha (1960 [5]), charakteryzuje się publikacja Chrystiana Norberg'a -Schulz'a pt. „Existance, Space and Architecture” (1971 [8]). Warto przywołać Kazimierza Wejcherta i jego „Elementy kompozycji urbanistycznej” z 1974 r. [9] będące ważnym polskim głosem lat 70. XXw. w dyskusji. Każda z tych publikacji próbowała nakreślić wytyczne kompozycyjne.

Analizując treści zawarte w ww. publikacjach dostrzega się duże analogie. Okazuje się, że bez względu na skalę rozpatrywanego problemu aranżacji i projektowania formy przestrzeń organizujemy zgodnie z klasycznymi zasadami w systemy punktów/węzłów, linii/ kierunków/dróg/ oraz płaszczyzn/rejonów - obszarów.

Tworzą one różnorodne układy - coraz częściej definiowane jako sieci (Filip A.J. 2015 [10]), dla których podstawy dała semilattice Christopher'a Alxander'a (1965 [6]).

Co ciekawe nie tylko to co człowiek kreuje przestrzennie, ale szerzej - w otaczającej rzeczywistości - odnajdujemy różnorodne powiązania sieciowe bez względu na skalę - od struktury neuronowej po astronomię galaktyk, od gry zespołowej po sieć utworu muzycznego (Tarapata Z. 2012 [11]).

Podobnie jest ze strukturą Systemu Przyrodniczego Miasta (SPM), którą krystalizują: elementy węzłowe istotne, ze względu na ,znaczenie klimatyczne, hydrologiczne i/lub biologiczne", korytarze/sięgacze - łączniki oraz tzw. otoczenie SPM - wielko przestrzenne obszary zasilania biologicznego położone poza terenem zabudowania, (Szulczewska B., Kaliszuk E. 2005 [1], Kaliszuk E. 2001 [12]). Czyli na SPM można spojrzeć również jak na rodzaj jednej z wielu sieci współtworzących miasto, co współcześnie również postuluje wielu urbanistów m.in. Gzell 2006 [13], Chmielewski 2010 [14]. 
a)

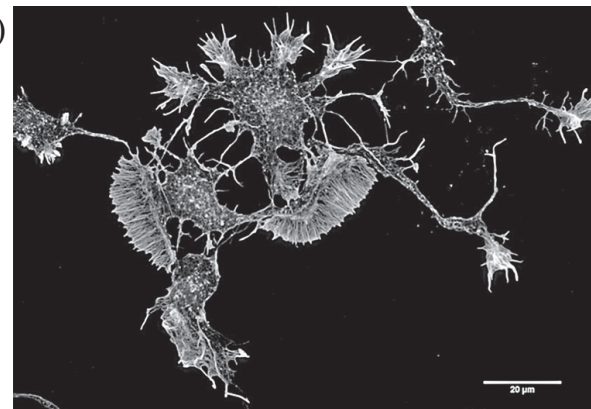

c)
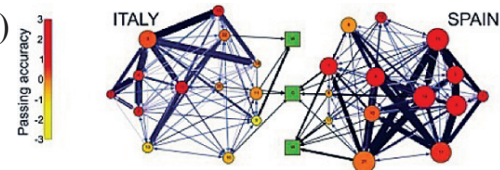

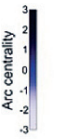
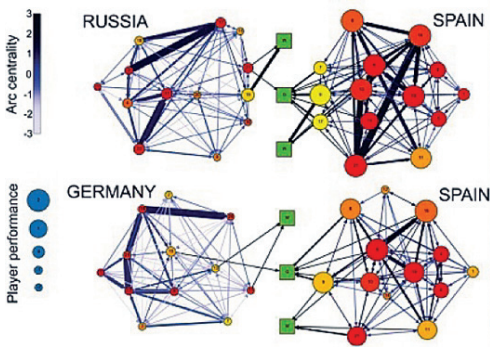

d) b)

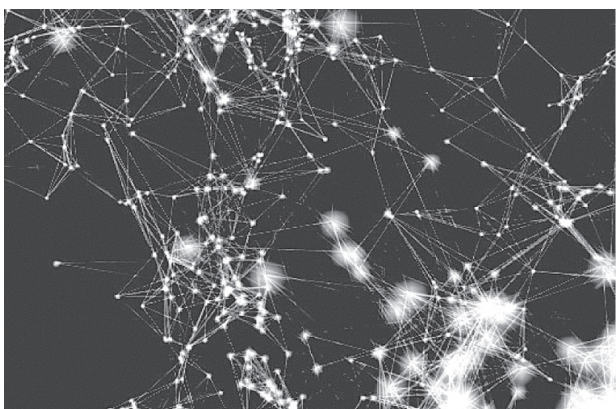
The idea

Represent music by network

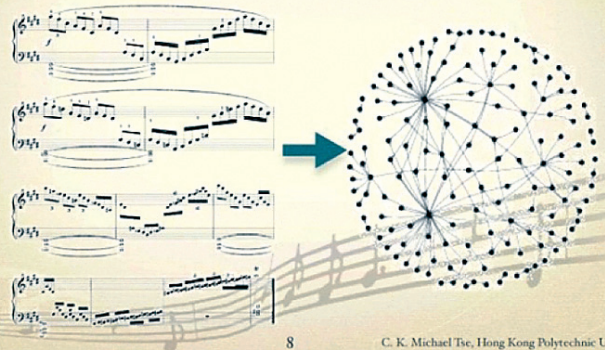

Rys. 2. a) Neuronowe powiązania sieciowe mózgu myszy (źródło:https://commons.wikimedia.org/wiki/ File:SUM_110913_Cort_Neurons_2.5d_in_vitro_488_Phalloidin_no_perm_4_cmle-2.png) b) Galaktyki połączone w sieć zależności - $\bar{m}^{-}$odel $\bar{i}$ animacja Center for Complex Network Research Northeastern Univeristy Physic Department w Bostonie, zespół prof. Alebrt’a László Barabási’ego (źródło: http://cosmicweb.barabasilab.com/viz/\#3), c) Wykorzystaniem systemu sieci do porównania gry zespołu Hiszpanii z rywalami podczas Mundialu w RPA w 2010r. (źródło: Duch J. Waitzman J.S., Amral L.A.N. 2010.: http://journals.plos.org/plosone/article?id=10.1371/ journal.pone.0010937), d) Sieciowy zapis utworu muzycznego -Tse M.C.K. Honkong Politechnic University, prezentacja (slajd nr 8) pt."Composing Music with Complex Networks - warsztaty IWCSN (International Workshop on Complex Systems and Networks 2009, Bristol - organizacja IEEE - Institute of Electrical and Electronics Engineers. (źródło:www.bristol.ac.uk/engineering/ media/engineering-mathematics/anm-meetings/iwcsn09/Tse-IWCSN2009.pdf

\section{Elementy węzlowe}

Miasto to organizacja przestrzenna tworzona przez ludzi i dla ludzi. Abstrahowanie jej od czynników społecznych pozbawia całą strukturę celowości. W ostatnich blisko trzydziestu latach organizacja społeczna przeszła fundamentalną transformację za sprawą rozwoju technologii informatycznych - Internetu, stając się społeczeństwem sieci (Castells M. 1996., 2007 [15]) Społeczeństwo sieciowe wydaje się nie mieć wymiaru przestrzennego - wiele wskazywałoby, że wręcz izoluje od niego - spotkanie w przestrzeni (w tym miejskiej) zastąpiono spotkaniem w sieci (Lis A. 2014 [16]). Niemniej jednak jak wskazują badania Aleksandry Lis (2014 [16]) oraz Marii Lewickiej (2012 [17]) potrzeba spotkania w realniej przestrzeni miejskiej współcześnie przeżywa renesans. Cenimy atrakcyjne miejsca, przywiązujemy się do nich, miejsce staje się ważnym czynnikiem zakorzenienia, zwłaszcza w dobie globalizacji i wzmożonej mobilności. Miejsce jako przestrzeń spotkania i rekreacji, którego idee rozwijane 
były od drugiej połowy XX w. (Heidegger. M. 1954 [18] 1977., Norberg-Schultz Ch. 1971 [19], 2000., Tuan Y.F. 1977., 1987 [20]) utożsamiane jest często z terenami zieleni - m.in. węzłowymi elementami SPM: skwerami, zieleńcami, parkami...itd. Nierzadko przybiera formę bardzo intensywnej koncentracji. Koncentracja ta może mieć w mieście dynamiczny i różnorodny rozkład, co mocno powiązane jest z czasem, porą roku oraz programem oferowanym przez konkretne obiekty. Na przykładzie Warszawy widać wyraźnie to zróżnicowanie. Pierwszy dzień wiosny przyciąga tłumy młodzieży skrzykującej się na portalach społecznościowych, na spotkanie nad Wisłę. Letnie wieczorne prezentacje wody-obrazu/światła-dźwięku w Multimedialnym Parku Fontann koncentrują liczne rzesze mieszkańców. Zimowy pokaz iluminacji w zabytkowym ogrodzie Wilanowa cieszy się dużą frekwencją.

Potrzeba kontaktu z przyrodą definiowana jako biofilia (Wilson E.O. 1984 [21], Kellert S.R. 1993 [22], Beatley T. 2010 [23], Salingaros N. 2015 [24]) jest widoczna od pierwszych dni wiosny w licznej frekwencji odwiedzających dziki brzeg praskich łęgów nadwiślańskich. Wolny czas społeczeństwo sieci wbrew pozorom chętnie spędza w kontakcie z przyrodą. To użytkownicy decydują gdzie się pojawią - lokalizacja węzła społecznej koncentracji związanej z aktywnością rekreacyjną i wypoczynkiem jest zmienna i elastyczna.

a)

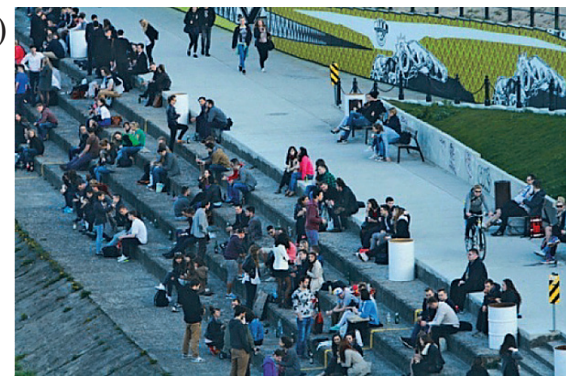

b)

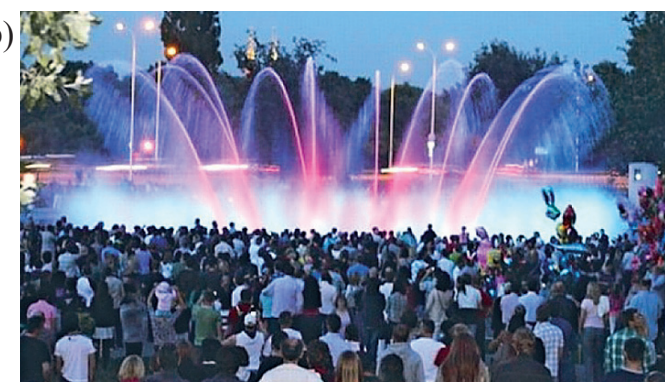

Rys. 3 a) Koncetracja młodzieży w pierwszy dzień wiosny nad Wisłą w Warszawie (źródło: https:// noizz.pl/spoleczenstwo/nad-wisla-mozna-pic-piwo-jest-wyrok-sadu/p5ln4ew?placement=WidgetSeeAlso\&position=0, b) Węzeł społecznej koncentracji w Multimedialnym Parku Fontann w Warszawie (źrodło:http://warszawa.naszemiasto.pl/tag/multimedialny-park-fontann.html

Ta elastyczność zależy m.in. od pojemności funkcjonalnej danego miejsca - obszaru węzłowego SPM. Na pytanie dlaczego miejsce jest żywe i funkcjonuje społecznie odpowiedź próbował uchwycić Wiliam H. Whyte w filmie oraz książce o tym samym tytule „The Social Life of Small Urban Space" (1980 [25]), która stała się bazą powołania organizacji Project for Public Spaces. PPS zajmuje się tzw. place making'iem - działaniami wspierającymi projektowanie i budowanie miejsc aktywnych społecznie. Ciekawą ideą PPS jest zasada siły 10 - Power of 10 (https://www. pps.org/reference/the-power-of-10/), mówiąca, że miejsce ma szanse stać się aktywne społecznie jeśli znajdzie się w nim minimum 10 powodów dla których warto je odwiedzić. Wymieniona biofilia (w przypadku punktów węzłowych SPM) jest tylko jednym z wielu powodów, względy rekreacyjne, programy kulturowe (np. pokazy multimedialne), kawiarnie, atrakcyjność zabytkowa, niepowtarzalność charakteru będą magnesami przyciągającymi odwiedzających.

\section{Potencjał elementów węzłowych}

Znamienne jest, że realizacja parku de la Villette będącego najgorzej ocenianego przez PPS wśród przestrzeni przyjaznych społecznie, stała się przełomowym podejściem do 
kreowania potencjału użytkowego parku miejskiego. W 1982r. Bernard Tschumi wraz zespołem pod wpływem inspiracji filozofii dekonstrukcji Jaques'a Derrid'y zaproponował odejście od modernistycznego funkcjonalizmu. Projekt oparto na trzech warstwach: linii - odpowiedzialnych za komunikację, punktów Folies - artystycznych, ideowo i kompozycyjnie ważnych, regularnie rozłożonych czerwonych form przestrzennych oraz płaszczyzn odpowiedzialnych za wnętrza parkowe. Folies - szaleństwa (thum. aut.) Tschumiego pierwotnie afunkcjonalne z czasem rozwoju projektu i jego realizacji, nabrały roli użytkowej m.in. stając się punktami widokowymi, miejscami lokalizacji kas, węzłów sanitarnych czy zaplecza technologicznego itp. Podobnie było z wnętrzami parkowymi projektowanymi jako przestrzenie prezentujące idee, a nie konkretne funkcje, które zyskały wyrazisty artystyczny charakter. Ich formę użytkową mieli zdefiniować sami użytkownicy. Dla przykładu Ogród Luster zaproponowany przez samego Brnard'a Tschumi'ego czy Ogród Winnicowy autorstwa Gilles'a Vexlard'a skupiły się na odbiciach i refleksach zachodzącego słońca, natomiast Ogród Energii - Alexander Chemetoff przedstawił symboliczną siłą wzrostu bambusowego lasu, wzmocnionego przez dźwiękowym kręgiem Bernhard'a Leitner'a. Wyraz artystyczny oraz stymulacja zmysłów człowieka okazały się nadrzędne w stosunku do funkcji użytkowych. Zanegowano także wartość izolacyjną zieleni. Przez ogród bambusowy, obniżony o kilka metrów w stosunku do powierzchni parku, przebiega kolektor instalacyjny stanowiący kanwę kładki zawieszonej ponad wnętrzem, a ścianom oporowym pozostawiono technologiczny charakter. Izolację zastąpiono integracją, elementy o negatywnym charakterze zamieniono w atuty i wyróżniki miejsca. Funkcje użytkowe de la Villette pozostawiono otwarte na interpretację odwiedzających rozszerzając potencjał rekreacyjny i szeroko rozumianą funkcjonalność.

Otwartość użytkową parku zapoczątkowaną przez Bernard'a Tschumi'ego współcześnie rozszerzono. Martin Prominski (2005 [26]) nakreślił podstawy pod tzw. projektowanie otwarte (open design) oparte na definicji krajobrazu rozumianego jako dynamiczny oraz otwarty system. Otwartość struktury krajobrazu i jej permanentna zmienność są badane od blisko 30 lat (Jackson J.B. 1984 [27], Bartman E., Bratman P. 1996 [28], Zinowiec-Cieplik K. 2003 [29]). Pełna akceptacja tego fenomenu w praktyce zawodowej zaowocowała stosunkowo nie dawno. Przejście od projektowania statycznych układów, gdzie świat przyrody utrzymywany jest na określonym przez projektanta poziomie, do pełnego projektowania procesów to dorobek początku XXI wieku.

Jako pierwszy, niezrealizowany przykład takiego podejścia Martin Promiski (2005 [26]) wskazuje projekt... parku de la Villette zespołu pracowni OMA pod kierunkiem Rem’a Koohlaas'a, który zdobył drugą nagrodę w konkursie z 1982r. W swojej wizji autorzy zdefiniowali przestrzeń jako nieprzewidywalny do końca, permanentnie formowany system - odeszli od dyktatu funkcjonalnego na rzecz stworzenia otwartej na interpretacje użytkowników struktury, podobnie jak zwycięski zespół B. Tshumiego. Tym razem zaproponowano cztery warstwy. „Główne elementy” miały tworzyć istniejące i projektowane budowle m.in. muzeum, sale koncertowej wystawiennicze itd., „Confetti”- stanowiły drobne wyposażenia jak kioski, toalety i niewielkie pawilony usługowe rozłożone regularnie (podobnie jak Folies w kompozycji Tschumi’ego), warstwa „Dostępu i Cyrkulacji” odpowiadała za system komunikacyjny, ostatni zaś czwarty poziom „Pasów” złożony był z sześciometrowej szerokości długich struktur przenikających całą przestrzeń parkową. Nowatorstwo pomysłu pasiastego układu polegało na kreacji potencjału, który w trakcie użytkowania mógł przybierać różnorodne funkcje w zależności od bieżących potrzeb i rozwoju samej przestrzeni. 
a)

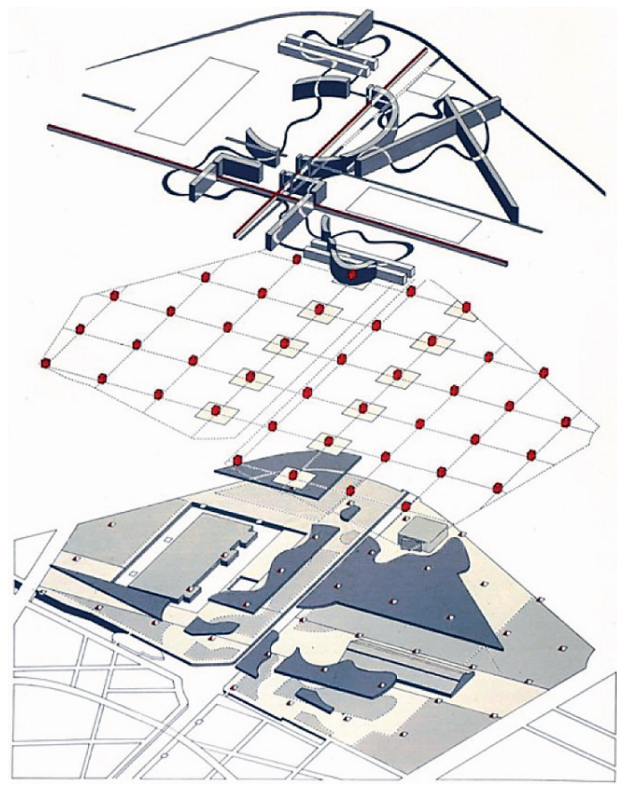

b)
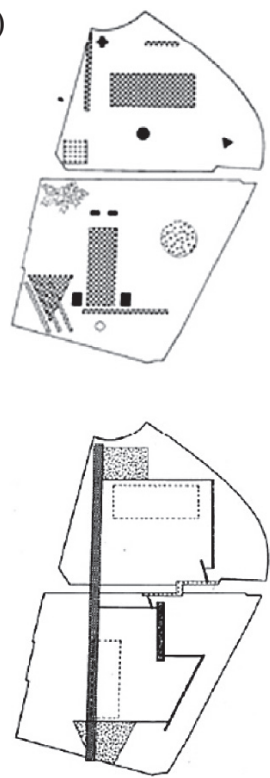
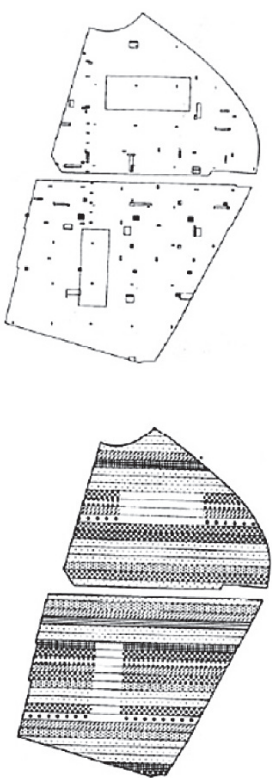

Rys. 4. a) Idea parku de la Villette zespołu Bernarda Tschumiego trzech warstw: linii, punktów - Folies i płaszczyzn. (źródło: http://www.bmiaa.com/concept-notation-bernard-tschumis-retrospectivetravels-to-basel/), b) Idea parku de la Villette zespołu OMA: główne elementy, „Confetti”, „Dostęp i Cyrkulacji” oraz „Pasma”. (źródło: ead.verhaag.net/fullpapers/ead06_id194_2.pdf)

Przykład de la Villette przez ostatnie 30 lat pokazał jak może on ewoluować. Zrealizowany zgodnie z założeniami Bernarda Tschumiego, jako swoisty eksperyment przestrzenny podlegał przemianom oraz sam stawał się miejscem ewolucji idei - zwłaszcza od początków XXI wieku. Na przełomie XX i XXI wieku (1999 - 2000) w zabytkowej Dużej Hali wystawowej miała miejsce ważna wystawa - Ogród Planetarny ukazująca piękno oraz ograniczoność ziemskiego ogrodu. Kuratorem przedsięwzięcia był Gilles Clément, który od połowy lat 80-tych XX wieku jest orędownikiem roztropności i szacunku w stosunku do kreacji krajobrazu, oraz ochrony dóbr przyrody. Jego idea i projekt Ogrodu w Ruchu dla parku Citroëna, którego inspiracją był urok i dynamika nieużytków, oparty został o akceptację zmienności spontanicznej roślinności zielnej. W swojej publikacji (Clement G. 1991 [30]) zachęcał do minimalizowania intensywnej uprawy na rzecz obserwacji i głębszego zrozumienia świata przyrody, gdzie rośliny mają prawo do okresu zimowego spoczynku, gdzie zmienność sezonowa, także w zakresie estetycznych walorów staje się wartością. Według Gilles'a Clément (1996 [31]), sztuka projektowa krajobrazu powinna być bardziej skupiona na obserwacji i zrozumieniu dynamicznego świata, tak - aby człowiek umiał lepiej korzystać z zasobów przyrodniczych. Wyprzedził on o blisko 20 lat idee ochrony bioróżnorodności, które współcześnie stają się obowiązującym standardem projektowym w kontekście malejących zasobów (MA 2005 [32]). Wystawa Ogrodu Planetarnego w parku - eksperymencie dopięła blisko 40 letni okres dyskusji o kurczących się zasobach, zapoczątkowany publikacją Klubu Rzymskiego z 1972 r. [33]. 
a)

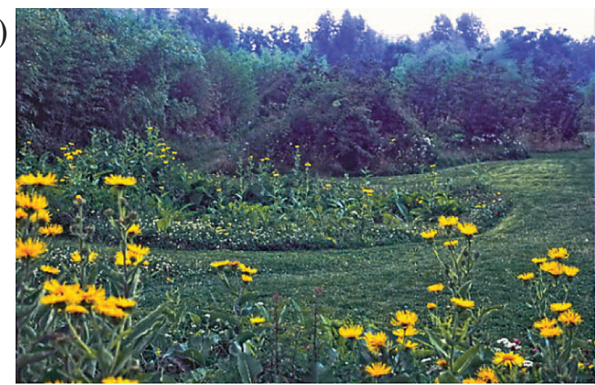

b)

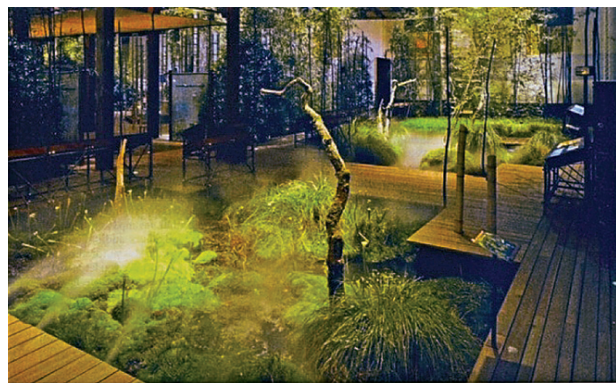

Rys. 5. a) Otwartość na procesy przyrodnicze - Ogród w Ruchu w parku Citroën'a (fot. G. Clémenet). (źródło: http://www.gillesclement.com/cat-banqueimages-andre-tit-banqueimages-andre), b) Piękno kurczących się zasobów przyrodniczych - Ogród Planetarny - wystawa w Dużej Hali de la Villette. (źródło: http://eac.crdp-limousin.fr/art-et-paysage/?s=jardin+Planetaire\&submit $=$ Rechercher)

\section{Otwartość na zmiany i procesy}

Park de la Villette uwolnił kompozycję od dyktatu funkcji, a Ogród w Ruchu z późniejszymi działaniami Gilles'a Clément otworzyła drogę do nowego zrozumienia kompozycji. Przykładów jest wiele, min. Park Krajobrazowy Duisbur Nord (projektowany i realizowany w latach 90-tych Latz +Parners) oparty na prawach sukcesji naturalnej, Park Millenium (1997-2004 Gustafson K., Gehry G., Kapoor A., Plensa J.) o szerokiej elastyczności programowej, park Niebieska Plaża (1990-1996 Ilex + DEVD) o industrialnej estetyce ze strefą przyrody otwartą na procesy, czy w mniejszej skali dowcipny i intrygujący projekt prof. Reinera Szmidt'a. palcu zabaw (BUGA 2005) - pofalowanej powierzchni na pozór bezużytecznej, której atrakcyjność formy zachęca do eksploracji.

Ciekawym a zarazem najbardziej zaawansowanym otwartym przedsięwzięciem jest Fresh Kills dla Staten Island autorstwa James'a Corner'a, który oparto na idei Lifscape krajobrazu godzącego potrzeby zarówno człowieka jak i przyrody. Powstał projekt, na który złożyły się trzy warstwy: Pasma (Threads) odpowiedzialne za przepływ wody, energii i materii, Reguły Matematyczne (Mats) stanowiące mozaikowy układ miejsc samowystarczalnych i odpornych środowisk, oraz tzw. Clusters - rodzaj wysp będących zasobami różnorodności roślinnej, zwierzęcej oraz rekreacyjnej. Całość w założeniu ma stanowić układ otwarty, trwały i odporny na zachodzące w przyszłości, a obecnie nieprzewidywalne procesy - park będzie bardziej kreowany przez upływ czasu oraz zachodzące w nim zmiany niż przez jednoznaczne formy i funkcje. Plan przedsięwzięcia został nazwany Matrixem co pokazuje, że już na poziomie projektowym obiekty SPM w świadomości twórców traktowane są współcześnie jak rodzaj sieci, gdzie operuje się pojęciami przepływów (energii, materii etc.) - pochodzących z języka badań sieci komunikacyjnych (Steenbrinka A.P. 1978 [34]) i społeczeństwa sieci (Catells M. 1996, 2007 [15]), koncentracji (procesów przyrodniczych/użytkowych) oraz porowatości (niedopowiedzeń otwartych na nieznane m.in. procesy i funkcje) - zaproponowanej przez prekursora projektowania otwartego Yona Friedmana w idei La ville spatiale $\mathrm{z}$ lat 1959-1960 (Wasilkowska A. Nowak A., 2009 [35]). 
a)

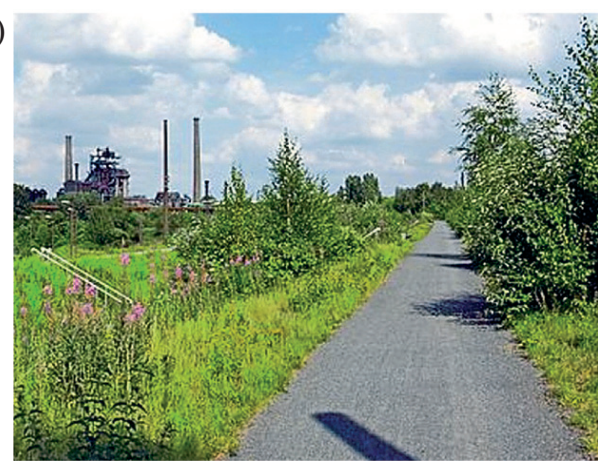

c)

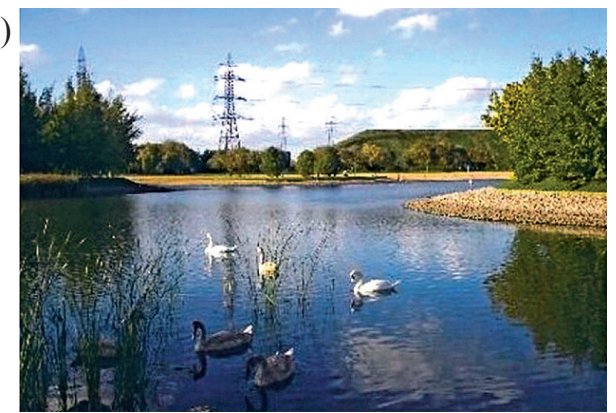

b)

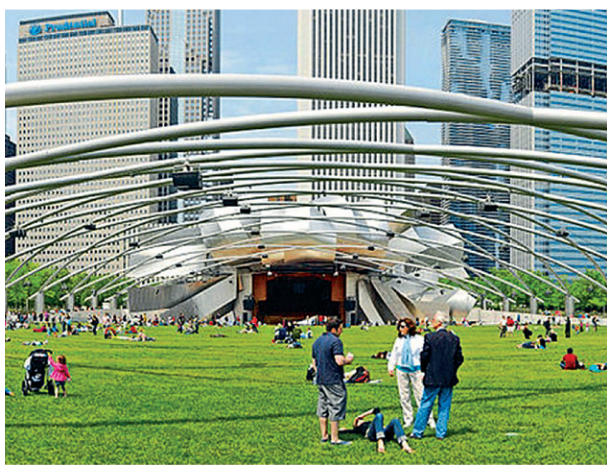

d)

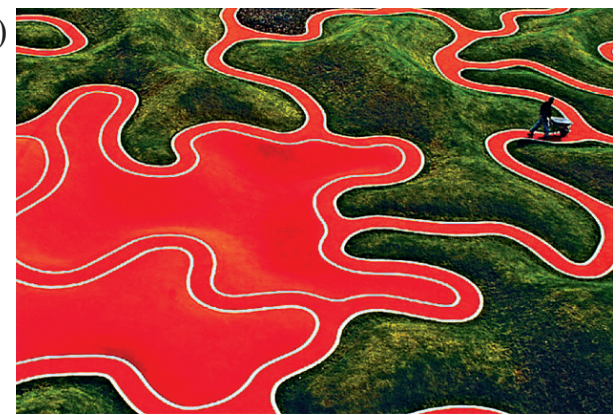

Rys. 6. a) Spontaniczność sukcesji naturalnej jako element kompozycji na przykładzie Parku Krajobrazowego Dusburg Nord. (źródło:https://commons.wikimedia.org/wiki/File:Landschaftspark_Duisburg-Nord___Landschaft.jpg), b) Łaczenie i rozszerzanie funkcjonalne - murawa rekreacyjna oraz sala koncertowa Pawilonu Pritzkera w jednym. (źródło: https://en.wikipedia.org/wiki/ Millennium_Park\#/media/File:Pano-chicago.jpg), c) Industrialny w formie Park Niebieska Plaża po 25 latach otwartości na sukcesję. (źródło:http://dandylan.uniterre.com/page2/\&thisy$=\&$ thism=\&thisd=), d) Plac zabaw jako otwarte funkcjonalnie miejsce rekreacji na wystawie BUGA 2005. (źródło: https://de.wikipedia.org/wiki/Bundesgartenschau_2005\#/media/File:BUGA_2005.jpg)

"Growing a new parkland over time"

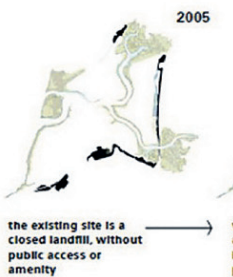

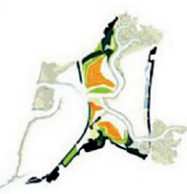

within a tew years. areas of the stre can
be reclatmed as userul
publlc landscapes

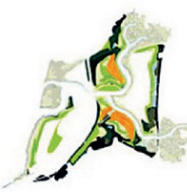

soon therarter, new park drives can con
Riknmond Avenue Riknmond Avenue
to theWest Snore Expressway and allow
access around the park

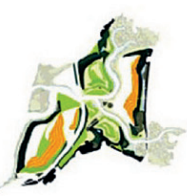

larger areas of the park
will be rectalmed as will be reclatimed as
public parkland over
time

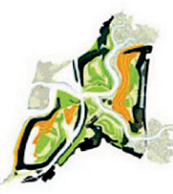

restaurants, curturat faclittles, sports
amentiles and other amenittes and other
recreatlonal uses witt
activate the site

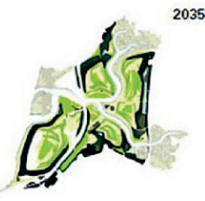

a mature blomatrix
within the next 30 years, Fresn Kills Park Years. Fresh Kills Park
may be transtormed
into a fully sustaliable. Into a tully surt
iving park

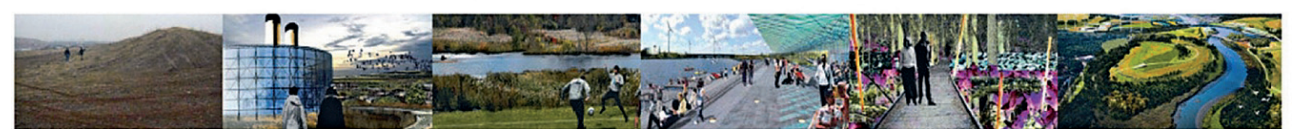

Rys. 7. Rozwój Marrix’a - Lifescape parku Fresh Kills projektu James'a Corner'a (źródło:http://www. archdaily.com/339133/landfill-reclamation-fresh-kills-park-develops-as-a-natural-coastalbuffer-and-parkland-for-staten-island) 
a)

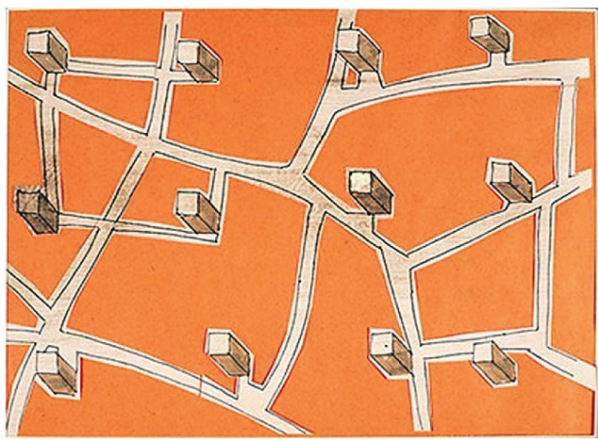

b)

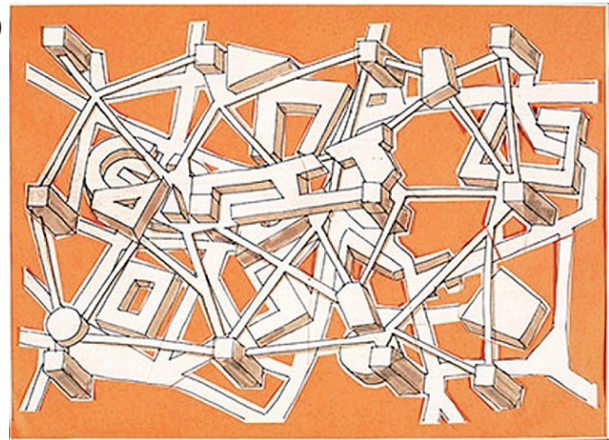

Rys. 8. a) Pierwsze propozycje miejskiego systemu otwartego - La Ville spatiale, 1959-1960, rysunek na papierze tuszem i akwarelą, 21 x $29.7 \mathrm{~cm}$ aut. Yona Friedman zbiory Les Turbulences Frac Centre. (źródło:http://www.frac-centre.fr/collection-art-architecture/friedman-yona/ville-spatiale-64.html?authID=72\&ensembleID=164), b) Pierwsze propozycje miejskiego systemu otwartego - La Ville spatiale, 1959-1960, rysunek na papierze tuszem i akwarelą, 21 x $29.7 \mathrm{~cm}$ aut. Yona Friedman zbiory Les Turbulences - Frac Centre. (źródło: http://www.frac-centre.fr/ collection-art-architecture/friedman-yona/ville-spatiale-64.html?authID=72\&ensembleID=164)

\section{Potencjał usług ekosystemowych}

Przejście od projektowania statycznych struktur elementów węzłowych SPM (parków, skwerów, zieleńców itd.) do projektowania otwartego na procesy i funkcje spowodował, że miejsca te zwiększyły swój potencjał. W zależności od potrzeb i sytuacji mogą być wykorzystywane w bardzo zróżnicowany sposób. W takim podejściu może tkwić niebezpieczeństwo ponieważ otwartość na zmiany może być niekiedy rozumiana także jako przyzwolenie na zabudowę. Narzędziem chroniącym przed presją zabudowy mogą okazać się usługi ekosystemowe powiązane z zieloną infrastrukturą.

Usługi ekosystemowe definiowane jako korzyści, które uzyskujemy dzięki środowisku przyrodniczemu (m.in. procesy przemiany energii słonecznej dwutlenku węgla i wody w proste związki organiczne w procesie fotosyntezy, regulacja żywności, rekreacja, turystyka, edukacja, inspiracja kulturowa itd.) mogą być wyceniane i wchodzić w majątek trwały miasta (COM(2013)249 final [36]). Idea usług ekosystemowych jest narzędziem pozwalającym syntetycznie przedstawić powiązania ekologii z ekonomią i ostatecznie ujednolicić oceny ekonomiczne i ekologiczne (Solon J., 2008 [37], MEA 2005 [31],). Mówiąc wprost pozwala na wycenę ekonomiczną usług świadczonych przez środowisko naturalne i określenie ,zielonego" majątku. Uświadamia wartość i rangę systemów zieleni (Costanza R. i in 1997 [38], Solon 2008 [37]).

Badacze z IGPiM, prof. Barbara Szczepanowska z dr Markiem Sitarskim, we współpracy z SGGW (Szczepanowska B. i.in. 2014) [39] wyliczyli łączną roczną wartość usług drzew przyulicznych Pragi Północ, obszaru badawczego między ulicami Targową - Zieleniecką - Zamoyskiego - Jagielońską - al Solidarności (okres badań 2011-2013) na ponad $2 \mathrm{mln}$ zł (2.016.000 zł). Obecnie przygotowywane są wnioski z badań usług świadczonych przez drzewa parku Praskiego w Warszawie (Jędraszko-Macukow M., Sitarski M. 2017 [40]), na podstawie zebranych danych poddanych obliczeniom metodą i-Tree ECO (US Forest Service). Badania metodą i-Tree ECO opracowano dla wielu miast, między innymi dla Londynu gdzie całkowity roczny zysk wynikający z usług drzewostanu oszacowano na 132,7 milionów $£$ (Valuing London〉s Urban Forest [41]). Według danych amerykańskich natomiast, 
inwestycja w zieleń jest opłacalna, a stopa zwrotu się potraja (każdy zainwestowany w drzewa dolar zwraca się trzykrotnie). Średnio w Stanach Zjednoczonych sto drzew ponad czterdziestoletnich przynosi roczne dochody 225.000 USD, a dojrzałe drzewo przez 50 lat wyemituje do atmosfery $\mathrm{O}_{2}$ o łącznej wartości 30 tys.USD (Borowski J. [42]). Trzeba przypomnieć, że w kontekście struktury urbanistycznej, SPM przeciwdziała powszechnym zjawiskom miejskiej wyspy ciepła. W Polsce na razie dokładnych badań w skali miasta nie robiono. Nie mniej jednak wyniki amerykańskie mogą zachęcać do podjęcia takiego trudu. Ciekawym przykładem może być Atlanta, w której dzięki zwiększeniu pokrycia terenów miasta zielenią (5 tys. nowo posadzonych większych drzew - średnica pnia $30 \mathrm{~cm}$ i 60 tys. mniejszych - średnica pnia $10 \mathrm{~cm}$ ) ograniczono zasięg wyspy ciepła o 1/3. (Szczepanowska H.B. 2007 [43]).

W zakresie usług ekosystemowych bardzo dobrze sprawdzają się realizacje zielonej infrastruktury m.in. zielonych dachów oraz żyjących elewacji. Badania sugerują, że jeśli przez okres dziesięciu lat wszystkie budynki w Chicago zostałyby wyposażone w zielone dachy ( $30 \%$ całkowitej powierzchni gruntów), to przyniosłoby to oszczędności w wysokości 100 mln USD rocznie ze względu na zmniejszone wymagania dotyczące obciążenia chłodzeniem (Peck S., Kuhn M. [44]). Dodatkowo zmniejszyłaby się emisja $\mathrm{CO}_{2}$ i innych szkodliwych związków powstających podczas pracy klimatyzatorów i produkcji energii.

W Polsce badania dotyczące zielonych dachów najbardziej zaawansowane są we Wrocławiu gdzie badacze skupiają się na gospodarce wodnej (Szajda-Binfeld E. i.in. 2012 [45], Burszta-Adamiak E. 2015 [46]). Natomiast jeśli chodzi o pozostałe funkcje ekologiczne to bazujemy na badaniach niemieckich prof. Mafred'a Köhler'a (np. 2001 [47]) i Marco Schmidt>a, (np. 2003 [48]), oraz doświadczeniach zapisanych w tzw. FLL (Forchungsgesellschaft Lnadschaftsentwicklung Lnadschaftsbau e.V [49]), które przetłumaczono na język polski (2015 [50]). W Warszawie były prowadzone badani pilotażowe (Baryła A., Sedlicka B, Kaczmarczyk A. 2015 [51]) zmian temperatury w zależności od pokrycia dachu zielonego (dach z ogrodem na budynku Neofilologii Uniwersytetu Warszawskiego), z których winka, że średnia różnica temperatur między powierzchniami pokrytymi roślinami, a nawierzchnią $\mathrm{z}$ desek wyniosła $7,23^{\circ} \mathrm{C}$. Zbliżone wnioski prezentują badania przeprowadzone w Krakowie gdzie temperatura dachu zielonego była niższa od temperatury dachów zabudowy staromiejskiej o ok. $8-10^{\circ}$ C. (Walawender J.P. 2015 [52]).

Podobnie funkcjonują zielone ściany w postaci fasad porośniętych pnączami lub zagospodarowane w formie ogrodów wertykalnych, izolują jak zielone dachy. Pnącza na elewacjach zmniejszają amplitudy dobowych wahań temperatury powietrza wypełniającego przestrzenie między warstwą liści, a ścianą około $4^{\circ} \mathrm{C}$. W letnie dni temperatura powietrza pod pnączami jest niższa o około $4-5^{\circ} \mathrm{C}$. Mniejszym wahaniom podlega także wilgotność powietrza, która pod liśćmi utrzymuje się na stałym poziomie do $90 \%$, w odniesieniu do wilgotności powietrza na zewnątrz bliskiej 100\%. W związku z tym uzyskuje się oszczędność energii 15-30\% rocznie (w klimacie umiarkowanym). Pnącza są roślinami bardzo wydajnym pod względem powierzchni liści - mają bardzo wysoki stosunek powierzchni biologicznie czynnej do powierzchni potrzebnej do wzrostu. Rozrośnięty winobluszcz pięciolistkowy zajmuje ok. $0,5 \mathrm{~m}^{2}$ gruntu, a powierzchnia jego liści w sezonie to $2600 \mathrm{~m}^{2}$ (Borowski J. 2013. [53]). Badania niemieckie na budynku Wydziału Fizyki (Architects Augustin and Frank) w Adlershoff w Berlinie dowodzą, że zacienianie pnączami południowej elewacji budynku generuje koszty w wysokości $1300 € /$ a co jest ponad dziesięciokrotnie tańsze od konwencjonalnych form osłaniania elektrycznymi roletami - które kosztują $16.250 € /$ a (Schmidt M. 2015 [54]). 
Przytoczone przykłady pełnionych funkcji oraz wartości usług ekosystemowych bardzo mocno przemawiają do wyobraźni, definiują zieleń jako jeden z ważniejszych, jeśli nie najważniejszych aktywów miasta. Przeprowadzenie wyceny usług ekosystemowych, umożliwia zaliczenie wartości środowiska przyrodniczego do majątku trwałego miasta jako „naturalnego kapitału zielonej infrastruktury" zgodnie z wytycznymi Komisji Europejskiej” (Szczepanowska H.B. i in. 2014 [39]). Wycena ekonomicznej wartości natury pozwala także spojrzeć na środowisko z perspektywy potrzeb społecznych a ich maksymalne spełnienie może tworzyć węzeł koncentracji rekreacyjnej. Wartość tych usług znacznie rośnie wraz z upływem czasu i dojrzałością ekosystemów (Szczepanowska H.B. 2001 za McPherson 1994 [55]), odwrotnie niż to jest w przypadku infrastruktury technicznej.

Tereny zieleni nie tylko tworzą zaplecze rekreacyjne i odpoczynkowe miast ale mają bardzo pozytywny wpływ na zdrowie człowieka. Badania prowadzone min. w Holandii i Stanach Zjednoczonych dowodzą, że zieleń w pobliżu zamieszkania obniża poziomu stresu i agresji (Szczepanowska H.B. 2001 [55], Borowski J. 2013 [56]). Parki, skwery i ogrody są ważnym miejscem spotkania i interakcji społecznych, rozwoju wspólnot i lokalnych społeczności (Gawryszewska B.J. 2009 [57]). Okazuje się, że brak kontaktu z przyrodą może doprowadzić do tzw. zespołu deficytu natury (Louv R. 2014 [58]) objawiającego się min. depresją, otępieniem, brakiem kreatywności oraz zanikiem umiejętności budowania więzi społecznych. Większość naukowców związanych z badaniami oddziaływania przyrody na ludzi, jest zgodnych, iż ograniczenia interakcji z naturą w okresie dzieciństwa, może doprowadzić do zachowań biofobicznych w dojrzałym życiu, wyobcowania, braku zrozumienia natury, a w konsekwencji do zaniku postaw eko-etycznych (White R. [59]). Kontakt z naturą niweluje wpływ stresu i pomaga dzieciom radzić sobie z przeciwnościami. Im częściej przebywają one na łonie natury tym większe czerpią korzyści (Wells N., Evans G. 2003 [60]).

Poruszając problematykę funkcji społecznych zieleni warto także wspomnieć o aspektach kulturowych budowania tożsamości lokalnych (Gawryszewska B.J., 2009 [57]), o symbolicznych i duchowych odniesieniach ogrodów kontemplacyjnych, czy wartościach artystycznych ukazujących duchowe/sakralne, także w kategoriach świeckich role natury.

\section{Podsumowanie}

Elementy węzłowe SPM pełnią różnorodne role integracyjne jako atrakcyjne tereny ze względu na potencjał rekreacyjny i użytkowy, są miejscem spotkania oraz budowania tożsamości. Sprzyjają temu współczesne trendy kształtowania krajobrazu miejskiego tzw. open design otwartego na różnorodność form użytkowych jak i akceptację dynamiki procesów przyrodniczych. Nie zawsze muszą być to działania „totalne” jak w przykładzie Fresh Kills. Często nowe ogniwo sieci SPM może być niewielkie ale za to o intensywny oddziaływaniu w myśl idei miejskiej akupunktury. I choć samo zjawisko akupunktury stosunkowo niedawno przeniesiono na grunt urbanistyczny (Cassagrande M. 2003 [61], Lerner J. 2014 [62]), to niewielkie ale silnie promieniujące zielone interwencje miejskie pojawiły się już w latach 60-tych XX w., na fali poszukiwania nowych rozwiązań miejskich. W Nowym Yorku powstał pierwszy park kieszonkowy (vest-pocket park), którego celem była poprawa życia mieszkańców Harlemu poprzez stworzenie alternatywy dla betonowej pustyni - powstał ogród dla lokalnej społeczności - mikro park - miejsce integracji, wspólnej uprawy oraz zabawy. Inicjatorką powstawania pocket park'ów była wielebna Linnette C. Williamson (1923-1990), - a pierwszą realizacją z 1965 r. - park kieszonkowy przy 128 ulicy zwany dzisiaj parkiem pamięci The Rev. Linnette C. Williamson Memorial (http://www.williamsonparks.org/revsilliamson/). Współcześnie 
mikro parki przeżywają prawdziwy renesans. Jako niewielkie przestrzenie mogą być szybko aranżowane przy niskim budżecie przez administrację publiczną - jako tereny rekreacyjne (przykładem może być seria ogrodów kieszonkowych dla Łodzi rozpoczęta w 2016 r.). U podstaw powstawania tych zielonych mikro punktów na mapie miasta, bywa także inicjatywa społeczna - wtedy powstają różnorodne ogrody społecznościowe integrujące lokalnych mieszkańców wokół uprawy ogrodu (o funkcjach min. ozdobnych, użytkowych, rekreacyjnych) w miejscu odzyskanym - między budynkami, itp. Mikro parki mogą być ważnym ogniwem życia społecznego, a także spełniać role ekologiczne wchodząc w SPM. Czasami sytuacja jest odwrotna - kiedy istniejące niejako zapomniane tereny zieleni poprzez zmianę użytkowania stają się formą akupunktury miejskiej - kreują silnie promieniujący węzeł integracji społecznej. Za przykład może posłużyć inicjatywa Otwarty Jazdów w Warszawie, gdzie różnorodność form użytkowania jest bardzo zróżnicowana: promocja ekologicznych upraw, działania artystyczne, edukacyjne, akademickie, rekreacyjne, promocyjne oraz integracyjne. Ponadto Jazdów, dzięki swojej otwartości - porowatości jakby powiedzieli specjaliści sieciowi, postrzegany jest jako element większej całości, jako ogniwo na szlaku Warszawskiej Drogi Kultury na Skarpie (inicjator Filip A.J. https://drogakultury.waw.pl/droga-kultury/\#czym-jest-droga-kultury), jako ważny punkt historyczny miasta oraz jeden z węzłów Nocy Muzeów.

a)

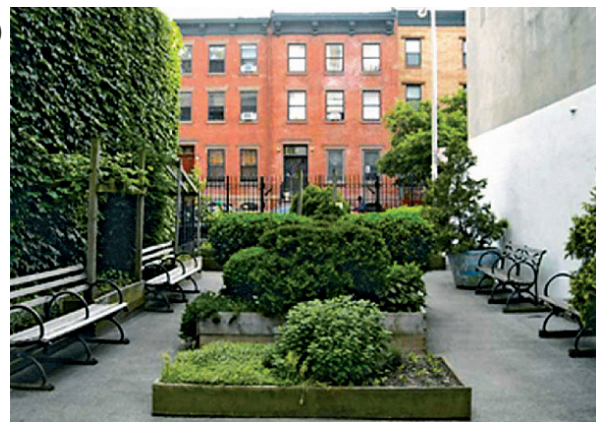

b)

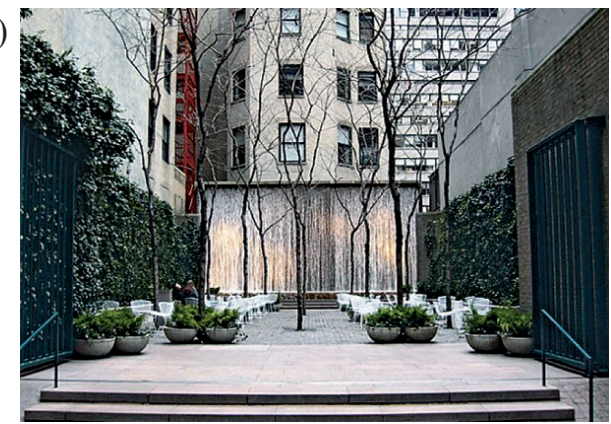

Rys. 9. a) Akupunktura miejska - pierwszy park kieszonkowy w Harlemie przy 128 ulicy - po renowacji The Rev. Linnette C. Williamson Memorial Park - z 1994 r. (źródło:https://stanley-hui.squarespace.com/vestpocket-park-1965/, b) Paley Park - najbardziej znany, publiczny park kieszonkowy założony na Manhatanie na prywatnej działce i z prywatnych funduszy - proj. Zion Breen Richardson Associates 1967. Park był obiektem badań i analiz w filmie The Social Life of Small Urban Spaces William'a H. Whyte'a. (źródło:https://en.wikipedia.org/wiki/Paley_Park\#/media/ File:Paley_Park_jeh.jpg

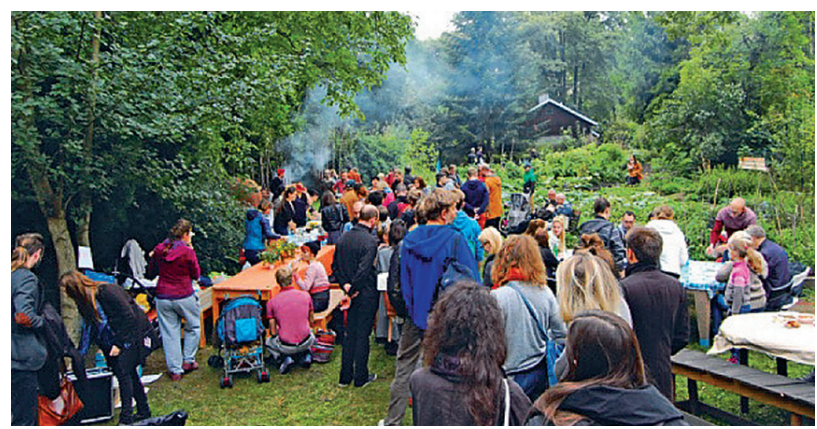

Rys. 10. Otwarty Jazdów - spotkanie w jednym z ogrodów. (źródło: http://warszawalokalnie.waw.pl/ partnerstwa/otwarty-jazdow-partnerstwo-dla-osiedla-jazdow/ 
Elementy węzłowe Systemu Przyrodniczego Miasta traktowanego współcześnie jako sieć przyrodnicza (Gzell S., 2006. [13], Chmielewski J.M. 2010 [14], Filip A.J., 2015 [10]) obok spełniania różnorodnych funkcji ekologicznych, świadczenia usług ekosystemowych, wchodzą w konteksty społeczne i kulturowe dzięki rozszerzanemu/otwartemu potencjałowi użytkowemu. Na sieć systemu przyrodniczego nakładają się/przenikają inne sieci: systemu rekreacyjnego, społecznych aktywności, kulturowych inicjatyw, edukacyjnych działań, historycznych odniesień... dzięki czemu węzły SPM zyskują potencjał integrujący/spajający. Im więcej sieci się splata $\mathrm{w}$ danym miejscu, tym rośnie siła 10, która wielokrotnie może przekroczyć swoją wartość w danym elemencie węzłowym SPM.

\section{Literatura}

[1] Szulczewska B., Kaliszuk E. Koncepcja systemu przyrodniczego miasta: geneza, ewolucja i znaczenie praktyczne [w:] Teka Kom. Arch. Urb. Stud. Krajobr. - OL PAN, 2005.

[2] Szumacher I. Funkcje ekologiczne parków miejskich. [w:] Prace i Studia Geograficzne tom 36. Wydawnictwa Uniwersytetu Warszawskiego, Warszawa, 2005.

[3] Wysocki Cz. Miasto jako specyficzne środowisko życia roślinności [w:] Nauka Przyroda Technologie 2008 Tom 2 Zeszyt 4 Dział: Ogrodnictwo, Wydawnictwo Uniwersytetu Przyrodniczego w Poznaniu.

[4] Sikorski P. Wplyw naturyzacji parku miejskiego na różnorodność florystyczna runa i trawników parkowych. Wyd. Wieś Jutra, 2013.

[5] Lynch K. The Image of the City, The Technology Press \& Harvard Univerity Press, Hraward, 1960. Lynch K. Obraz miasta, Wydawnictwo Archivolta, Michał Stępień, Kraków, 2011.

[6] Alexander Ch.. et al. A City is Not a Tree. [in:] Architectural Forum 1965 (Vol 122, No 1, April 1965, pp 58-62 (Part I), and Vol 122, No 2, May 1965, pp 58-62 (Part II), Alexander Ch.. et al. A City is Not a Tree, 2015. https://www.rudi.net/books/200 - [data dostępu 15.07.2017]. Alexander, Ch. A City is Not a Tree. [w:] Jenks J. Kropf K., 2013, Teorie i manifesty architektury współczesnej, Grupa sztuka Architektury, Warszawa, 2013.

[7] Alexander Ch. at all. A Pattern Language: Towns, Buildings, Construction. Oxford University Press, 1977. Alexander Ch. i in. Język Wzorców, A pattern language, Gdańskie Wydawnictwo Psychologiczne, Gdańsk, 2008.

[8] Norber-Schulz Ch. Existence, Space and Architecture, Praeger Publishers, London. 1971. Norber-Schulz Ch. Bycie, przestrzeń, architektura, Wydawnictwo Muratora sp. z o.o., Warszawa, 2001.

[9] Wejchert K. Elementy kompozycji urbanistycznej, Arkady, Warszawa. 1974.

[10] Filip A.J. Miasto jako struktura sieci wspótzależnych, [w:] Studia Ekonomiczne. Zeszyty Naukowe Uniwersytetu Ekonomicznego w Katowicach, Nr 217 / 2015, Uniwersytet Ekonomiczny w Katowicach, Katowice.

[11] Tarpata Z. Czy sieci rzadza światem? Od Eulera do Barabasiego, [w:]. Biuletyn Instytutu Systemów informatycznych 10 (2012) 31-51, Instytut Systemów Informatycznych, Wydział Cybernetyki, Wojskowa Akademia Techniczna, Warszawa.

[12] Kaliszuk E. Funkcjonowanie systemu przyrodniczego miasta na przykładzie Warszawy, 2001. www.geo.uj.edu.pl/publikacje.php\%3Fpdf\%3D000025_028\%26notka\%3DRXdhIEthbGlzenVrIDIwMDEgRnVua2Nqb25vd2FuaWUgc3lzdGVtdSBwcnp5cm9kbmljemVnbyBtaWFzd GEgbmEgcHJ6eWtsfWFkemllIFdhenN6YXd5+\&cd=1\&hl=pl\&ct=clnk\&gl=pl [data dostępu 15.07.2017.].

[13] Gzell S. Miasto sieć i jego społeczność. Ku konkretyzacji zapisów Nowej Karty Ateńskiej 2003, [w:] Jeżewska I. (red.) Nowe przestrzenie w mieście. Ich organizacja i funkcje. Wydawnictwo Uniwersytetu Łódzkiego, Łodź, 2006. 
[14] Chmielewski J.M. Teoria urbanistyki w projektowaniu i planowaniu miast, Oficyna Wydawnicza Politechniki Warszawskiej, Warszawa. 2010.

[15] Castells M. The Rise of the Network Society, The Information Age: Economy, Society and Culture Vol. I. Cambridge, MA; Oxford, UK: Blackwell, 1996. Castells M. Społeczeństwo sieci., PWN, Warszawa, 2007.

[16] Lis A. Aktywizacja przestrzeni publicznych w mieście - ocena potencjatu miejsc, Wydawnictwo Uniwersytetu Przyrodniczego, Wrocław, 2014.

[17] Lewicka M. Psychologia miejsca., Wydawnictwo Naukowe Scholar, Warszawa, 2012.

[18] Heidegger. M. Bauen Wohnen Denken, vortrage un Ausfsatze II, Pfullingen, 1954. Heidegger. M. Budować mieszkać, myśleć, Czytelnik, Warszawa, 1977.

[19] Norber-Schulz Ch. Existence, Space and Architecture, Praeger Publishers, London. 1971. Norber-Schulz Ch. Bycie, przestrzeń, architektura, Wydawnictwo Muratora sp. z o.o., Warszawa, 2001.

[20] Tuan Y.F. Space and Place: the Perspective of Experience, University of Minnesota Press, 1977. Tuan Y.F. Przestrzeń i miejsce, PIW, Warszawa. 1987.

[21] Wilson E.O. Biophilia. Cambridge. Harvard University Press, 1984.

[22] Kellert S.R. The Biophilia Hypothesis. Island Press, 1993.

[23] Beatley T. Biophilic Cities, Integrating Nature into Urban Design and Planning, Island Press, 2010.

[24] Salingaros N. Biophilia and Healing Environments - Healthy Principles for Designing Built World., Metropolis, Terrapin Bright Green, LLC, 2015. http://www.terrapinbrightgreen.com/ wp-content/uploads/2015/10/Biophilia-Healing-Environments-Salingaros-p.pdf [data dostępu 15.07.2017].

[25] Whyte W.H. The Social Life of Small Urban Space, Conservation Foundation, 1980.

[26] Prominski M. Designing Landscape as Evolutionary System, [in:] The Design Journal An International Journal for All Aspects of Design 8 (3) (2005). ead.verhaag.net/fullpapers/ead06 id194_2.pdf [data dostępu 15.07.2017].

[27] Jackson J.B. Discovering the Vernacular Landscape, New Haven, Yale University Press, 1984.

[28] Bartman E., Bratman P. Studium przyrodniczych cech krajobrazu regionu Elblaskiego dla potrzeb turystycznych i rekreacyjnych, [w:] Studia i Materiaty - Krajobrazy 14, wyd. OOZK Narodowa Instytucja Kultury, Warszawa, 1996.

[29] Zinowiec-Cieplik K. Rzeźba w krajobrazie - geneza i rozwój, praca doktorska, archiwum Katedry sztuki Krajobrazu SGGW, 2003.

[30] Clément G. Le Jardin en Mouvement, Sens et Tonka, Paris, 1991. http://www.gillesclement.com/ cat-mouvement-tit-Le-Jardin-en-Mouvement [data dostępu: 15.07.2017]

[31] Clément G. Thomas et le voyageur, Albin Michel, Paris, 1996. Clément G., Le jardin Planétaire http://www.gillesclement.com/cat-jardinplanetaire-tit-Le-Jardin-Planetaire [data dostępu: 15.07.2017]

[32] Millennium Ecosystem Assessment. Ecosystems and Human Well-Being: Synthesis, Island Press, Washington, DC. 2005.

[33] Meadows D.H., Meadows D.L., Randers J., Behrens W.W. III. The Limits to Growth, Universe Books, 1972. http://www.donellameadows.org/wp-content/userfiles/Limits-to-Growth-digital-scan-version.pdf [data dostępu] Meadows D.H., Meadows D.L., Randers J., Behrens W.W. III. Granice wzrostu, Państwowe Wydawnictwo Ekonomiczne Warszawa,1973.

[34] Steenbrinka P.A. Optymalizacja sieci transportowych, Wydawnictwo Komunikacji i Łączności, Warszawa, 1978.

[35 Wasilkowska A. Nowak A., (red.). Warszawa jako struktura emergentna: Em_Wwa 1.0, Bęc Zmiana, Warszawa, 2009.

[36] COM(2013)249 final http://ec.europa.eu/environment/nature/ecosystems/docs/green_infrastructures/1_EN_ACT_part1_v5.pdf https://www.teraz-srodowisko.pl/media/pdf/aktualnosci/2557-zielona-infrastruktura.pdf [data dostępu 15.07.2017].

[37] Solon J. Koncepcja „Ecosystem Services” i jej zastosowania w badaniach ekologiczno-krajobrazowych, [w:] Problemy ekologii krajobrazu, 2008, vol. 21, 25-44. 
[38] Costanza R. et al. The value of the world's ecosystem services and natural capital. Nature, 387 (1997) 253-260.

[39] Szczepanowska H.B., Sitarski M., Suchocka M. Funkcjonowanie drzew i krzewów w warunkach oddziaływania infrastruktury technicznej miasta. Artykuł powstał na podstawie referatu, wygłoszonego podczas konferencji: MIASTO IDEALNE - MIASTO ZRÓWNOWAŻONE Planowanie przestrzenne terenów zurbanizowanych i jego wpływ na ograniczenie skutków zmian klimatu Warszawa, 24 października 2014 r. [http://ucbs.uw.edu.pl/wp-content/uploads/SitarskiSzczepanowska-Funkcjonowanie-POPRAW..pdf].

[40] Jędraszko-Macukow M., Sitarski M. Możliwości szacowania ustug ekosystemowych Parku Praga Park $w$ Warszawie metoda i-tree Eco. Prezentacja 16 maja 2017 podczas seminarium „, Drzewa w mieście - wartość, korzyści, strategia”; organizatorzy: Uniwersytet warszawski, Centrum Nauk Biologiczno-Chemicznych Uniwersytetu Warszawskiego, Uniwersyteckie Centrum Badań nad Środowiskiem, SITO / NOT.

[41] Valuing London's Urban Forest, Results of the London i-Tree Eco Project. https://www.forestry.gov.uk/pdf/LONDONI-TREEECOREPORT151202.pdf/\$FILE/LONDONI-TREEECOREPORT151202.pdf [data dostępu 15.07.2017.].

[42] Borowski J. Ile warte sq drzewa w mieście?, 2010. http://www.muratorplus.pl/technika/zrownowazony-rozwoj/ile-warte-sa-drzewa-w-miescie_68688.html [data dostępu 15.07.2017.]

[43] Szczepanowska H.B. Ekologiczne, społeczne i ekonomiczne korzyści z drzew na terenach zurbanizowanych. [w:] Człowiek i Środowisko, 31 (3-4) (2007) 5-26. https://www.igpim.pl/publikacje/str07_3-4/Szczepanowska.pdf [data dostępu 15.07.2017]

[44] Peck S., Kuhn M. Desing guidelines for green roofs. https://www.eugene-or.gov/DocumentView. aspx?DID=1049 [data dostępu: 15.07.2017]

[45] Szajda-Birnfeld E., Pływaczyk A., Skarżyński D. Zielone dachy. Zrównoważona gospodarka wodna na terenach zurbanizowanych, Uniwersytet Przyrodniczy, Wrocław, 2012.

[46] Burszta-Adamiak E. Zielone dachy jako element zrównoważonych systemów odwadniających na terenach zurbanizowanych. Wydawnictwo Uniwersytetu Przyrodniczego, Wrocław, 2015.

[47] Köhler M., Schmidt M., Grimme F.W., Laar M., Gusmão F. Urban Water Retention by Greened Roofs in Temperate and Tropical Climate. IFLA-Congress, Singapore, 2001.

[48] Schmidt, M. Energy Saving Strategies though the Greening of Buildings the Example of the Institute of Physics of the Humboldt University in Berlin-Adlershof, [in:] RIO 3-World Climate \& Energy Event, 1-5 December 2003, Rio de Jnaeiro, Brazil.

[49] FLL - Forchungsgesellschaft Lnadschaftsentwicklung Lnadschaftsbau, e.V.

[50] Wytyczne dla dachów zielonych, FLL, 2015., DAFA, Opole.

[51] Baryła A., Sedlicka B., Kaczmarczyk A. Zmiany temperatury różnych form użytkowania zielonego dachu. [w:] Infrastrutura i ekologia terenów wiejskich. Nr IV/1/2015, POLSKA AKADEMIA NAUK, Oddział w Krakowie 2015, s. 1081-1088 Komisja Technicznej Infrastruktury Wsi. http://dx.medra.org/10.14597/infraeco.2015.4.1.086.

[52] Walawender J.P. Zielona infrastruktura $w$ miastach - dachy zielone $w$ procesach adaptacji do zmian klimatu, 2015. http://zielonainfrastruktura.pl/dachy-zielone-w-procesach-adaptacji-dozmian-klimatu/ [data dostępu: 15.07.2017.]

[53] Borowski J. Dlaczego warto sadzić i pielęgnować drzewa?, 2013. Stowarzyszenie na Rzecz Ochrony Krajobrazu Kulturowego Mazur „Sadyba” https://sadybamazury.wordpress.com/2013/04/06/ dlaczego-warto-sadzic-i-pielegnowac-drzewa-jacek-borowski/ [data dostępu 15.07.2017.]

[54] Schmidt M. Making the city compact more livable and resilient thanks to the greening., Presentation 19th May 2015 on Hotel de ville de Paris. https://api-site.paris.fr/images/72760 [data dostępu 15.07.2017]

[55] Szczepanowska H.B. Drzewa w mieście, Hortpress, Warszawa, 2001.

[56] Borowski J. Bezcenne drzewa, Warszawa, Związek Szkółkarzy Polskich. http://www.zszp.pl/pliki/ MPO07-11s.60-61.pdf [data dostępu 15.07.2017.]

[57] Gawryszewska B.J. Revitalisation as a social process - the work with local communities, [in:] International Symposium Jointly Organized by IAPS-CSBE 'Culture\&Space in the built environment 
network' and the IAPS - Housing Network: Revitalising Built Environments: Requalifying Old Places for New Uses, 2009.

[58] Louv R. Ostatnie dziecko lasu, mamania, Warszawa, 2014.

[59] White R. Benefits for Children of Play in Nature. https://www.whitehutchinson.com/children/ articles/benefits.shtml] [data dostępu 15.07.2017.].

[60] Wells N., Evans G. Nearby Nature: A Buffer of Life Stress Among Rural Children. Environment and Behavior, 35(3) (2003) 311-330.

[61] Casagrande M. From Acupuncture to the Third Generation City, [in:] La ville rebelle. Démocratiser le projet urbain, Gallimard, Editors: Jana Revedin, 2014.

[62] Lerner J., 2014., Urban Acupuncture, Island Press.

\section{Źródla internetowe [data dostępu 15.07.2017]}

https://www.pps.org/reference/the-power-of-10/

http://www.williamsonparks.org/revsilliamson/

https://drogakultury.waw.pl/droga-kultury/\#czym-jest-droga-kultury

\section{Źródła ilustracji [data dostępu 15.07.2017]}

Rys. 1a. https://www.rudi.net/books/200

Rys. 1b. https://www.rudi.net/books/200

Rys. 1c. https://www.rudi.net/books/200

Rys. 1d. https://www.rudi.net/books/200

Rys. 2a. https://commons.wikimedia.org/wiki/File:SUM_110913_Cort_Neurons_2.5d_in_vitro_488 Phalloidin_no_perm_4_cmle-2.png).

Rys. 2b. http://cosmicweb.barabasilab.com/viz/\#3

Rys. 2c. http://journals.plos.org/plosone/article?id=10.1371/journal.pone.0010937

Rys. 2d. www.bristol.ac.uk/engineering/media/engineering-mathematics/anm-meetings/iwcsn09/Tse-IWCSN2009.pdf

Rys. 3a. https://noizz.pl/spoleczenstwo/nad-wisla-mozna-pic-piwo-jest-wyrok-sadu/p5ln4ew?placement=WidgetSeeAlso\&position $=0$

Rys. 3b. http://warszawa.naszemiasto.pl/tag/multimedialny-park-fontann.html

Rys. 4a. http://www.bmiaa.com/concept-notation-bernard-tschumis-retrospective-travels-to-basel/

Rys. 4b. ead.verhaag.net/fullpapers/ead06_id194_2.pdf

Rys. 5a. http://www.gillesclement.com/cat-banqueimages-andre-tit-banqueimages-andre

Rys. 5b. http://eac.crdp-limousin.fr/art-et-paysage/?s=jardin+Planetaire\&submit=Rechercher

Rys. 6a. https://commons.wikimedia.org/wiki/File:Landschaftspark_Duisburg-Nord_-_Landschaft.jpg

Rys. 6b. https://en.wikipedia.org/wiki/Millennium_Park

Rys. 6c. http://dandylan.uniterre.com/page $2 / \&$ thisy $=\&$ thism $=\&$ thisd $=$

Rys. 6d. https://de.wikipedia.org/wiki/Bundesgartenschau_2005\#/media/File:BUGA_2005.jpg

Rys. 7. http://www.archdaily.com/339133/landfill-reclamation-fresh-kills-park-develops-as-anatural-coastal-buffer-and-parkland-for-staten-island).

Rys. 8a. http://www.frac-centre.fr/collection-art-architecture/friedman-yona/ville-spatiale-64.htm1?authID $=72$ \&ensembleID $=164$

Rys. 8b. http://www.frac-centre.fr/collection-art-architecture/friedman-yona/ville-spatiale-64.htm1?authID $=72$ \&ensembleID $=164$

Rys. 9a. https://stanley-hui.squarespace.com/vestpocket-park-1965/

Rys. 9b. https://en.wikipedia.org/wiki/Paley_Park\#/media/File:Paley_Park_jeh.jpg

Rys. 10. http://warszawalokalnie.waw.pl/partnerstwa/otwarty-jazdow-partnerstwo-dla-osiedla-jazdow/ 


\title{
Nodes in the city green system, as a urban integration potential
}

\author{
Kinga Zinowiec-Cieplik \\ Department of Architectural-Urban Design, Faculty of Architecture, Warsaw University of Technology, \\ email: ckinga@wp.pl
}

\begin{abstract}
Urban greenery system a significant part of urbanized landscape, may be understood as "areas with specific characteristics identified and designated using the principles of ecology and landscape ecology, the main aim of which is to regulate the ways the natural city environment functions" ( Szulczewska B., Kaliszuk E. 2005 [1]). Greenery system assumes the leading role in building a sustainable and resilient urban environment. The green system structure, according to the generally accepted theory of urban composition (Lynch K. 1960 [5], Wejchert K. 194 [9].) is crystallized by the nodal elements, which,in this context, are vital,due to "climatic, hydrological and/or biological significance" (Szulczewska B., Kaliszuk E.2005 [1]). While considering city composition together with its landscape as a complex of many layers, such as communication, development, infrastructure and greenery, is it necessary to to emphasize the important role of their mutual penetration, which complements the essence of the functioning of thisvery dynamic and variable city organism. Changes in one of the layers cause distortion in the others. Therefore, the relationships that binds the layers are crucialand their accumulation and dynamics will determine whether the nodal point will eventually be developped. The greenery structure is too fragile with regard to the brutality of communication systems and buildings. However, in the light of the contemporary needs to build a healthy, friendly living environment opened to the change in creative design (Prominski M.2005 [26]), (Prominski M.2005 [26]), the natural system shows potential towards the integration of urban space.
\end{abstract}

Keywords: city node, urban green systems, urban space integration. 
